\author{
Luis ERnesto Cervera Gómez* \\ RODOLFO RUBIO SALAS**
}

\title{
BASIC CRITERIA FOR A SUSTAINABLE WATER MANAGEMENT AT THE U.S.-MEXICO BORDER: THE CASE OF AMBOS NOGALES
}

\begin{abstract}
This article is aimed to analyze some basic criteria for a sustainable use of water in an international watershed shared between Mexico and the United States. The study area comprises the region of A mbos $\mathrm{N}$ ogales, which is located inside the Upper Santa Cruz River Basin. This portion of the watershed represents the main ecosystem and the main source of water for urban and rural populations located at this region. Following criteria of sustainability the authors are retaking and adapting a set of guidelines proposed by the Pacific Institute for Studies in D evelopment, Environment, and Security, to the case of A mbos Nogales; this guidelines refers the next elements: basic water requirement to maintain human health; basic water requirement to maintain the health of ecosystems; water quality to meet certain minimum standards; human actions and the long-term renewability of freshwater stocks and flows; the collection of data on water resources, use and quality; institutional mechanisms to prevent and resolve conflicts; and a democratic process of water planning and decision making. These twin cities have a long history of cooperation and conflict linked to water resources. This fact makes available enough information to create a kind of diagnostic about the water management inside a binational arena, allowing this fact to explore possibilities for a better water resources management under a sustainable regime from an international perspective.

Keywords: Sustainability, Binational Water Management, A mbos N ogales Region.
\end{abstract}

\footnotetext{
* Profesor-investigador adscrito a la dirección general regional noroeste de el COLEGIO DE LA FRONTERA NORTE EN CIUDAD JUÁREZ, CHIHUAHUA. E-mail: Icervera@colef.mx **PROFESOR-INVESTIGADOR ADSCRITO A LA DIRECCIÓN GENERAL REGIONAL NOROESTE DE EL COLEGIO DE LA FRONTERA NORTE EN CIUDAD JUÁREZ, CHIHUAHUA. E-mail: rodrubio@colef.mx
}

Artículo recibido en septiembre de 2003.

Artículo aprobado en diciembre de 2003. 


\section{RESUMEN}

En este artículo se analizan algunos criterios básicos para el uso sustentable del agua en una cuenca internacional localizada en la frontera de México con los Estados Unidos de Norteamérica. El área de estudio comprende la región conformada por las ciudades de Nogales, Sonora y Nogales, A rizona y conocida como A mbos Nogales y localizada dentro de la cuenca alta del Río Santa Cruz. Esta subcuenca representa el principal ecosistema y la principal fuente de agua para la subsistencia de las poblaciones rurales y urbanas de ambos países. En este estudio se retoman algunos principios básicos de sustentabilidad desarroIlados por el Pacific Institute for Studies in D evelopment, Environment, and Security y adaptados pare el caso de Ambos Nogales. En general, estos criterios comprenden los siguientes elementos: requerimientos básicos para sostener la calidad de vida de los pobladores y la salud de los ecosistemas; calidad del agua que reúna estándares mínimos en calidad y cantidad; las acciones de la humanidad y sus impactos en la tasa de renovabilidad; colección de datos del recurso agua; procesos democráticos en la planeación y en la toma de decisiones y por último los mecanismos institucionales para la resolución de conflictos. Ambos Nogales cuentan con una larga historia de cooperación y conflicto ligadas al uso y manejo del agua. Este hecho hace posible el contar con suficiente información para en primera instancia generar un diagnóstico sobre el manejo del recurso agua en una arena binacional, permitiendo explorar las posibilidades para un mejor manejo del agua bajo un régimen sustentable y desde una perspectiva internacional.

Palabras clave: Sustentabilidad, Administración binacional del agua, Región de ambos Nogales.

\section{INTRODUCTION}

Forty percent of world population subsist sharing hydrologic basins divided by political, ethnical or economic boundaries (Samson and Charrier, 1997). In these border regions, the importance of water resources is so great that it can be the source of international conflicts. In exploring water as a border issue the best material can be founded where a historical record of information like ingredients of cooperation and conflict exists. Such it is the case of the border between Mexico and the U.S. (Ingram, 1995).

From a shared water resources perspective (boundaries are defined by the drainage area of the watersheds lying in both countries), Woodard and Durall (1996) had estimated that the border area between Mexico and the U.S. overlay about 403,456 
square kilometers $\left(\mathrm{Km}^{2}\right)$ lengthening about 3,072 $\mathrm{km}$ between the Golfo de Mexico and the Pacific Ocean with a population of about 9.5 millions of inhabitants. In this border region, surface water from the Rio Bravo/ Rio Grande, the Colorado River, and the Tijuana River had been appropriated and distributed under an international agreement signed in 1944. In this article the study area is mainly represented by the Santa Cruz River, which is an important tributary of the Gila River inside the Lower Colorado Basin. The binational component of this river is named The Upper Santa Cruz River and over it lays the cities of N ogales, Sonora and Nogales A rizona. These twin cities are also referred as Ambos N ogales. This sub-basin is al so theland for rural communities from the Santa Cruz County, Arizona and for rural population of the Municipio of Santa Cruz, Sonora.

The main goal of this document is to discuss a set of guidelines driving the sustainable water use presented by Morrison et al (1996) and adapted in this job for the knowledge of the binational water issues. These criteria arethefollowing: (1) to providea basic water requirement to people in terms of good health conditions; (2) to dispose a water portion to restore and give maintenance to the ecosystems; (3) to maintain water under quality standards according to its use; (4) to dispose of quantitative and qual itative water data; (5) to develop institutional mechanisms to prevent and to solve conflicts about water use; (6) planning and decision makings considering all involved parts; (7) human actions will not affect the renewability water rates of the aquifers and surface waters. Every criterion is applied to thestudied region and it could hel $p$ to address the water resource management under sustainability criteria.

\section{BACKGROUND}

A mong relevant environmental problems existing in border regions like the M exico and the United Sates there is nothing more important than water (Ingram, 1995). To remark this fact, just remember the current conflicts sustained between these two 
countries for the waters al lotted in the Rio Grand Basin under the 1944 water treaty, which has been magnified for a prolonged drought during the last decade. Thus, this U.S.-M exico frontier can offer us an excellent opportunity to study border issues related to water management given a historic relationship of cooperation and conflict carry out for these two nations, where a political borderline al so divide the natural ecosystems.

Ingram (1995) pointed out that whatever action taken by every nation affect shared resources, such as the atmosphere, oceans, watershed, aquifer, wildlife, migration corridors, and other resources from theneighbor nation. Such actions have been taken by Nogales, Sonora, and N ogales, A rizona, so far, sinceboth cities share the upper region of the water system in Santa Cruz river basin; they influence its natural transformation gradually.

Several authors have discussed the case of A mbos N ogales like a highly illustrative example of binational water problems. Like other border cities, these provide a wide spectrum of environmental problems which include surface and subsurface water pollution, over pumping, inadequate water supplies. This without consider its highly vulnerability during flood or drought events. However, in a moreoptimistic vision Ingram (1995) sustained that given the scal e of the water issues in A mbos N ogales, these water issues could be understood and confronted in a better way than other metropolitan border cities, such as Tijuana-San Diego and Ciudad Juarez-El Paso. The fact of sharing an important resource is unavoidable, this becausethese cities subsist exploiting the same waters sources existing in a watershed which naturally do not recognize borders. Therefore, this situation of physically shared ecosystems presents the challenge to establish policies of exploitation and administration of water in order to address a more sustainable use of water in a binational region. It is the last characteristic of binationality that makes the understanding and definition of sustainability criteria much more complex.

A strong component of sustainable development is the use of water through an equilibrated exploitation of its surfaces and 
subsurfaces components in a hydrological region whose boundaries and potentials can be technically measured. According to the OECD (1998) in its document titled "Towards Sustainable Development" the fact of relate water extraction versus its renewability rate; it is a central point. Dahal (1995) claimed that to determine a sustai nable water extraction of a renewable resource is important to know the extraction rate and thewater pumped in a given period in relation to the total volume available at the beginning and final steps of the same period.

Although the concept of sustainability can hold several meanings for different peopleor institutions, Loucks and Gladwell (1999) pointed out that sustainability is a unifier concept, which emphasize the fact to consider the future at long term, such as the present. Preceding idea includes the future of economic, environmental, ecological and social impacts resultants from actions and decisions taken in the present.

Based on general concepts Gleick at al. 1996 had defined sustainable water as: "The use of water to sustain human society to endureand flourish in an undefined future without undermine integrity of the hydrologic cycle or ecologic system depending upon it". This concept can be argued as a merely philosophical and hard to achieve in practice. N evertheless, approximation to a possiblestatus of sustainability requires the establishment of criteria addressed to the systems supplying water resources, with the goal of to be considered sustainable. These criteria can be defined regarding to: (1) design, management and operation of physical infrastructure; 2) environmental quality or ecosystem's health; 3) society and institutions; (4) economy and finances; 5) human health and well being; and 6) planning and technological development (Loucks and Gladwell, 1999).

Under the umbrella of sustainable use of water concept, it is necessary to define society components and ecosystems respectiveto studied area. Thus, society will berepresented by urban and rural communities from Ambos Nogales' region, while the ecological systems given sustenance to these communities are represented by the Upper Santa Cruz River Basin, and Los Alisos 
Estudios Fronterizos, Nueva época, vol. 4, núm. 7, enero-junio de 2003

Wash. LosA lisos wash is a tributary of the Magdalena River located to thesouth of N ogales, Sonora, and the use of its waters constitute a inter-basin transference.

This article analyzes the ecosystem on a watershed basis; it is a way to establish natural boundaries to an ecosystem. Hogan in 1993 had proposed to usetheecosystem watershed as a study unit in order to understand relationships among natural processes and human society. Furthermore, Hogan had defined the hydrologic basin as a strategic ecosystem to the observation and analysis of socio-demographicand environmental relationships. However, the former Hogan's concept do not considered the international component for those basins shared for two or more countries. Surface and groundwater supply from Ambos Nogales is totally obtained from three sub-basins. These are The Upper Santa Cruz River Basin, LosAlisos Wash, which is a tributary of the Magdalena River and Los Nogales Wash that is a tributary of the Santa Cruz River.

\section{Socio-eConomic conditions in Ambos Nogales}

While the main geographic reference had been derived from the space occupied for the Upper Santa Cruz River Basin, the cities of Nogales, Sonora and Nogales Arizona are the main populated areas demanding its water resources. Historic prevailing socioeconomic conditions of this region, such as the distances from main commercial supply centers and thefreetrade of good and services between them, had been propitiated an specific area of economic integration, based on interaction among individuals and institutions of both sides of the U.S. Mexico border. As a consequence, the main result of this process is a geographical sui generis context of economic interdependence between these paired cities, which arelocated in a continuous surfacetechnically divided by a border line. Consumption of goods and services; commercial trades; parental and friendships networks; and the operation of transnational enterprises having branches in both cities creates a kind 
of interweave that can be defined like a metropolitan binational zone (Alegría, 1990). The last century's quarter, installation and operation of maquiladora industry in the border U.S.-M exico region endowed to this region a current prospect never seen before, encouraging at the same time the economic nexus previously established. In the former context, the socio-economic complementarities of A mbos N ogales have some cornerstones elements to emphasize.

First of all, stand out somesocio-demographic indicators, which dynamic reflect different population growing patterns. For example, thesetwin cities has had a similar population by theyear of 1910, counting about 3,117 and 3,514 inhabitants for the cities of N ogales, A rizona and Nogales, Sonora respectively. However, to the end of last century Nogales, A rizona had just 20,878 inhabitants, while the city of N ogales Sonora scored up to 156,854 inhabitants. Then, there are high marked differences of growing population rate during the last 90 years in A mbos N ogal es. By the 2000 year Ambos Nogales region was scoring up to 177,732 inhabitants; from which $78.4 \%$ belongs to the Mexican side. The growing rate presented by the Mexican city during the above analysed period was al ways higher than the State of Sonora and even higher than the whole Mexican country growing. Central explanation for this kind of increased population rates resides in the fact of a constant flow of migrants since 40 's until the middle 60's, as a product of the U.S. program established from 1942 to 1964 to engage M exican workers. Afterwards, due to some transformations experienced by the border M exican economy, which main catalyst was and still is the maquiladora industry. Thanks to its impacts over the urban workers market, which exert a migrants attraction for both kinds temporal and permanents (Rubio, 2001).

While its North American counterpart has been a city which historically depends upon commercial activities and thoserelated to city services, the city of N ogales, Sonora during the last third of past century was witnessed a radical change in its economic structure. Thus, from an economy cantered in commerce and 
services became to city with a highly industrialized profile. Supporting this fact, census data from 2000 indicates that the city of N ogales, A rizona had concentrated about $84.7 \%$ of its employed population in activities related to commerce and services; while in N ogales, Sonora it was the industry of transformation counting with a little more than a half (50.95\%) of its entire economically active population. As a matter of fact, it is the presence of maquiladora industry explaining this phenomenon; in fact, this Mexican city is considered the more dependable for the employment generated by the maquiladora (Pick et al., 2001). Likewise, human migratory flows coming from other Sonora's Southern localities and neighbouring sates are the principal labour force of the maquiladora industry. In such grade that it represents about threequarters of total workers. This situation has been propitiated by two main processes which had been occurring in M exico. First, the adjusted economic activities having connection to the exterior, in which case the Northern Mexican region had wined primacy over the once industrial centers located at Mexico's City, Guadal ajara, and Monterrey. Furthermore, changes in migratory patterns of M exico; in sometime thesecities were the main targets receiving migrants, but now migrants are moving to medium populated cities (greater than 100,000 inhabitants) such as N ogales, Sonora.

In this new economic scenario, the City of Nogales, A rizona had been converted into the main offerer of commerce and some basic services for the Mexican inhabitants, at the same time functioning as the place for offices and storage of insumos and final products from maquiladora industry physically based on Nogales, Sonora. As was discussed above, a strong interdependence relationship between both cities obligate to propose water concerns like a binational issuegoing a step forward of the fact of a shared watershed. Thus, sustainability criteria for use of water shared in this region must necessarily included in a binational context. 


\section{The upper Santa Cruz River basin}

This binational hydrologic region is shaped by the drainage area of the Santa Cruz River. This river begins in Arizona the San Rafael Valley and drains the Patagonia M ountains to the west, Canello Hills to the north and Huachuca Mountains to the east. It flows south into M exico making a $56 \mathrm{~km}$ loop, and reenters the United Stats just east of Nogales (see Fig. 1). The river flows north to Tucson, and then joins the Gila River about $19 \mathrm{~km}$ southwest of Phoenix. Its length is over $360 \mathrm{~km}$ (Schwalen and Shaw, 1857). TheU pper S.C.R.B referred at this study was configured taking as an outl et point the USGS's gauging station (site with instruments to get measures of the river flows) identified as Santa Cruz River near N ogales ( $\mathrm{N}$ o. 09480500). This sub-watershed has an estimated area of about $1328.33 \mathrm{~km}^{2}$; from which $863 \mathrm{~km}^{2}$ ( 66 percent) belong to Mexican territory.

The Santa Cruz River flows perennially (year-round) in the San Rafael Valley at the river's head waters, and downstream form the Nogales International Wastewater Treatment Plant (NIWWTP). However, most of the Santa Cruz' tributaries even the main channel runs ephemerally during long periods of the year. In general, precipitation is the main factor producing runoffs, which are extremely variable. As a consequence the average flow has a very poor significant regarding to the expected average flow each year (De la Torre, 1970). Focused on the binational area it is necessary to define inputs and outputs runoffs from the system. As input can considered the stream runoff measured near to Lochiel, A rizona; this data is registered by the USGS at thegauging station \#090480000. Here, theaverage runoff estimated for 39years periods from 1949 to 1988 was about 2,910 ac-ft (3.6 M m³) (ADWR, 1980). A sa main output, theaverage flow entering to the U.S. side near to N ogales, A rizona was measuring about 20,400 ac-ft/ year ( $25.1 \mathrm{~mm}^{3} /$ year). Former figures emphasize the fact that most of the stream runoff produced registered in this basin are coming from the Mexican drainage area. Furthermore, it was estimated that $500 \mathrm{ac}-\mathrm{ft} / \mathrm{yr}\left(0.6 \mathrm{Mm}^{3}\right)$ are entering to the U.S. side through 
"underground" flow. Cervera (1998) reports that the Santa Cruz basin provides $45-50 \%$ of drinking water supply for Nogales, Sonora. Also, this region sustains the $100 \%$ of productive activities of the Municipio of Santa Cruz. Furthermore, this region also provides a huge portion of the water requirements of Nogales, $A Z$, such as, an important portion of the water demands of the Santa Cruz County farmers.

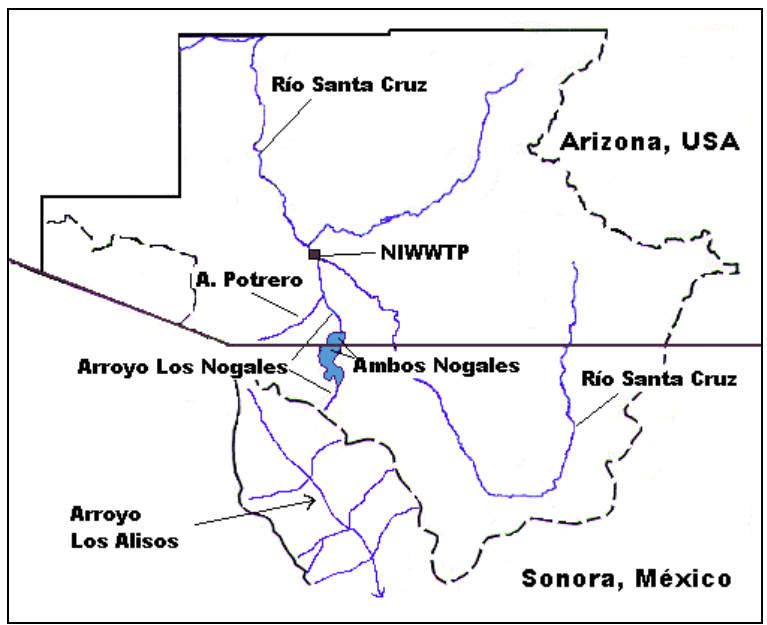

Figure 1. Location of A mbos Nogales and the Santa Cruz River.

The EPA (1999) had indicated that the city of Nogales, Sonora withdraw from the Santa Cruz River throughout its well fields (located at Mascareñas, Santa Bárbara and Paredes) 5.7 millions of gallons per day. With this pumping rate and guessing that it is constant, it can be estimated an annual pumping rate of about $7.87 \mathrm{Millions}$ of cubic meters $\left(\mathrm{M} \mathrm{m}^{3}\right)$.

Constituting an inter-basin water transfer between Los Alisos sub-basin and Nogales wash sub-basin, N ogales Sonora withdraw from the well fields existing at the Los Alisos wash, a pumping rate of about $6.8 \mathrm{mgd}$ (289 liters per second: Ips). Thus, a total about $9.39 \mathrm{M} \mathrm{m}^{3} /$ year is entering to $\mathrm{N}$ ogales, Sonora and increasing drastically the output flow going to the U.S. side of the basin. 
A water balance study conducted by Cervera (1995) suggests that this binational region has a natural capacity or natural recharge of about $24.22 \mathrm{M} \mathrm{m}^{3}$ in a yearly basis. Also, he found that under an equilibrated exploitation regime, where the extraction does not overpass natural recharge, this system may provide a pumping rate of about 768 Ips for both sides of the basin. However, this exploitation regimemust beconsidering seasonal and year to year variations of the natural recharge, overall during drought conditions.

\section{LOS N OGALES WASH}

TheN ogales wash originates in M exico; it is a tributary of the Santa Cruz River. It is over its almost entire drainage area where the city of Nogales, Sonora and Nogales, A rizona lays. The N ogales Wash' main channel has a total length of about $27 \mathrm{~km}$, from which 12 are inside the Municipio of Nogales and the reminding $15 \mathrm{~km}$ inside the Santa Cruz County. Its runoffs are present only during precipitation events. However this wash has a constant runoff supplied for wastewaters generated from Both Nogales (IBWC, 1998). It is important to note that the alluvium underlying Los Nogales wash receives recharge from the wash, and from leaking water and sewer lines.

Historically, A mbos N ogales had used the main N ogales wash channel to conduct its wastewaters (urban and industrial) until to reach the Nogales International Wastewater Treatment Plant (NIWWTP) where these flow receive treatment. The NIWWTP costs are financed by Both Countries. A ccording to Minute 276 from the 1944 international water treaty, Mexico has the rights to recapture its corresponding portion of the effluent for a possible reuse (9.9 million gallons per day of treatment capacity). Initially, the city of Nogales, AZ was responsible for this treatment plant, however, since 1998 itsoperation and maintenancewastransferred to the IBWC (EPA, 1999). Table 1 is showing the wastewater volume generated for Both Nogales and received for treatment in the NIWWTP. 
Estudios Fronterizos, Nueva época, vol. 4, núm. 7, enero-junio de 2003

TABLE 1. Urban wastewaters generated for A mbos Nogales.

\begin{tabular}{|c|c|c|c|c|c|c|}
\hline \multirow[t]{2}{*}{ M onth } & \multicolumn{3}{|c|}{$\begin{array}{l}\text { M onthly volumes in milliards } \\
\text { of cubic meters (2000) }\end{array}$} & \multicolumn{3}{|c|}{$\begin{array}{l}\text { A verage daily flows in milliards } \\
\text { of cubic meters (1952-2002) }\end{array}$} \\
\hline & $\begin{array}{l}\text { Nogales, } \\
\text { Son. }\end{array}$ & $\begin{array}{l}\text { Nogales, } \\
\text { AZ }\end{array}$ & $\begin{array}{l}\text { A mbos } \\
\text { N ogales }\end{array}$ & M ax & Min & A verage \\
\hline Jan & 1091 & 642 & 1733 & 93 & 2.5 & 24.2 \\
\hline Feb & 1048 & 604 & 1652 & 80.4 & 2.5 & 24.9 \\
\hline Mar & 1156 & 667 & 1823 & 85.7 & 2.8 & 24.7 \\
\hline Apr & 946 & 688 & 1634 & 69.2 & 2.6 & 23.3 \\
\hline May & 891 & 764 & 1655 & 59.4 & 2.1 & 22 \\
\hline Jun & 855 & 705 & 1560 & 62.5 & 2.6 & 20.6 \\
\hline Jul & 1374 & 360 & 1734 & 68.1 & 2.6 & 21.4 \\
\hline Aug & 1282 & 441 & 1723 & 75.6 & 2.8 & 23.2 \\
\hline Sep & 1243 & 451 & 1694 & 67.9 & 3 & 24.5 \\
\hline Oct & 1623 & 435 & 2058 & 87.2 & 2.6 & 24.8 \\
\hline Nov & 1559 & 621 & 2180 & 84.7 & 3 & 24.6 \\
\hline Dec & 1301 & 716 & 2017 & 75.9 & 1.3 & 24.5 \\
\hline Yearly & 14369 & 7,094 & 21463 & 93 & 1.3 & 23.6 \\
\hline
\end{tabular}

SOURCE: IBWC, Western Boundary Water Bulletin, 2002. [Online] Available at: www.ibwc.state.gov

For the 2000 year, effluents generated by N ogales, Sonora were representing 66.94 percent of the total treated volume in the NIWTP. Future projections show significant increases of the binational wastewaters (see table 2). Given the highest rates of population growth in Nogales, Sonora, it can be expected that effluents generated by this city may represent about 82.8 percent of the total effluent treated in the NIWWTP. Thus, constant increases in a yearly basis had been forced to continuous changes and expansions of this Treatment Plant.

TABLE 2. Wastewater flows projections for Ambos Nogales.

\begin{tabular}{|lllll|}
\hline City/ year & \multicolumn{1}{c}{$\mathbf{1 9 9 6}$} & \multicolumn{1}{c}{$\mathbf{2 0 2 0}$} & \multicolumn{1}{c}{$\mathbf{2 0 3 5}$} & \multicolumn{1}{c|}{$\mathbf{2 0 5 0}$} \\
\hline Nogales, AZ & $3.8 / 4687$ & $4.1 / 5057$ & $5.0 / 6167$ & $6.2 / 7648$ \\
Nogales,Son. & $9.2 / 11348$ & $19.8 / 24423$ & $23 / 28370$ & $28.6 / 35278$ \\
Totals & $13.0 / 16035$ & $23.9 / 29480$ & $28.0 / 34537$ & $34.8 / 42925$ \\
\hline
\end{tabular}

Units in thousands of acres-pie/ units in thousands of cubic meters.

SourCE: Morehouse, B., R.H. Carter, and T.W. Sprouse (2000). 


\section{BASIC CRITERIA FOR A SUSTAINABLE USE OF WATER AT THE binational Santa Cruz River Watershed}

This section analyzes a set of seven criteria for a sustainable use of water, which were originally proposed by Morrison et al (1996) from the Pacific Institute for Studies in D evelopment, Environment, and Security. These criteria have coincidence with those proposed by Loucks and Gladwell (1999). Even though former criteria were not developed for binational regions, in this job these criteria are analyzed in a binational water management context for Ambos Nogales region. Existing information will allow to analyze and to compare the following sustainable criteria for both cities.

\section{Criteria 1: to PROVIDE a BASIC WATER REQUiRem ENT TO PEOPLE IN TERMS OF GOOD HEALTH}

It is this sustainability criteria which represent the strongest challenge, and more critically for thecity of N ogales, Sonora. As a matter of fact the Mexican city has been experiencing since its foundation, problems of water supply, which is currently themore complex issue to solve. Ingram (1995) emphasized that explosive population increase experienced by Nogales during the last decade is the main cause of water supply. Nevertheless, it is not only the presence of more people if not the way they are distributed in thenew urban settlements (colonias). Thesenew areas usually are located over hills with high terrain slopes. Thus, topographic conditions make difficult any effort to providewater infrastructure and other services. A study conducted by Barrios and Cervera (2000) detail topographic conditions of some colonias, such as coIonia Heroes having maxim slopes of about $70 \%$, and slopes between $52 \%$ and $44 \%$ for the colonias Peñalosa and Chula Vista respectively.

By 1997, total water supply for Nogales was about 782 liters per second (Ips), from which only 550 Ips (70\%) was considered as secure. Thus, for this year the city was facing a deficit about $30 \%$. To trait to fulfill its water requirements, the city of N ogales, 
Estudios Fronterizos, Nueva época, vol. 4, núm. 7, enero-junio de 2003

Sonora is pumping groundwater asfollows: a pumping rateo about 250to 300 Ips areextracted from the Santa Cruz well fields and 300 Ips moreare pumped from LosA lisos well fields. Additionally, 100 Ips are extracted from several wells existing inside the city. The total water supply pumped from theformer mentioned wells fields are not enough to cover its water require-ments. Thus, COAPAES, which is themunicipal institution res-ponsiblefor water and sewage systems, reports that the current drinking water system has only an $85 \%$ of coverage. It is important to not that only $39 \%$ out of the $85 \%$ of the users connected to the local supply system, counted on a regular 24 hour service. Other important matter is that most of the infrastructure for supplying drinking water in N ogales, Son, is 30 years old and it requires immediate rehabilitation, because a high percentage of water loss is due to this fact. Very similar situation has the sewage system, which only cover $75 \%$ of the city (COCEF, 1996).

COAPAES reports that N ogales water municipal system has the capacity to provide 250 liters per person per day (Ippd). If this former figure is compared with the 200 Ippd recommended by theUN for developing countries, it can be assumed that N ogales's supply can be considered apparently adequate to provide good health conditions. However, other sources reveal that thereal water supply by inhabitant is about 150 lppd. Under any possiblescenario theN ogales, Sonora municipal water supply is very low compared with the capacity of Nogales AZ water system, which provide a service of about 180 gallons per person per day (697 lppd), this figure is 2.72 times greater than the Mexican side. At a very different situation Nogales, A rizona' water system has a 100 percent of coverage and also their futures demands are assured by 2040 (Cervera, 1997).

\section{Criteria 2: to dispose a WATER PORTION tO Restore AND GIVE MAINTENANCE TO THE ECOSYSTEMS}

Article 88, part I of the TitlellI of the Mexican Ley General de Equilibrio Ecológico y la Protección al A mbiente(L.E.G.E.P.A.) stipulatethat 
correspond to the State and society the protection of ecosystems and the equilibrium of natural components having influence in the hydrologic components. Part II of same Article mention that the sustainable use of natural resources must be performed without affect the ecological equilibrium. In fact this second criteria is highly considered by the Mexican law, but its level of application can be considered very poor or null. First, because exist a lack of knowledge or current environmental conditions of theriparian system and its basic water requirements to subsist. Second, there are no important initiatives to conserve riparian ecosystems.

Given thehistoricand present useof surfaceand subsurfacewaters to support productive activities and urban needs, it can besuggested that theecosystem of theSanta Cruz River is highly human impacted. As a matter of fact this former perennial runoff had changed to a moreephemeral condition presenting runoff only during precipitation events. Then, this watershed had its hydrologic components seriously changed in a possibleirreversiblemanner.

Although this area is consi dered highly impacted, theU.S. side of same basin presents different hydrologic conditions, due principally to a better water management strategy which is much more conservative. The Santa Cruz Active Management Area (SCAMA) considers inside its exploitation policies that quantity of water required for theriparian ecosystem to subsist. For instance, in a water balance developed for the SCAMA it was established a volume of $25,800 \mathrm{Mm}^{3}$ / year just to sustain the current riparian ecosystem. This volume is respected and used like a policy to regulatewater pumping. Parallel to this situation, institutions and society implement restoration practices of the riparian ecosystem. As a good example, it is necessary to emphasize the job that had been done by the "Friends of the Santa Cruz River".

Wastewater treated in the NIWWTP play a very important role in the restoration of the riparian ecosystem and recharging the aquifer. However, it is just the U.S. side taking advantages of the treatment plant effluent. Since its creation the effluents produced in this plant are being spilled over the river bed, just 
downstream of the treatment plant. This discharge forms a perennial runoff which extends about 16 miles $(25.6 \mathrm{~km})$ reaching Tubac, A rizona. (N ADBank, 2002). Consequently, substantial benefits had been achieved for the Riparian ecosystem downstream the NIWWTP. Furthermore, theartificially induced recharge has been used by the Santa Cruz County to get future exploitation credits.

Patten (2002) reports that the effluents had enriched nutrient levels and elevated the groundwater table. These effluents plus precipitation runoff had allowed development and a rapid grow of riparian forest composed principally by cottonwoods (Populus fremontii) and willows (Salix gooddingii). At the same time, this riparian vegetation became a natural mechanism to reduce water pollutants agents and its nutrient levels. Given the proven benefits of the reuse of the effluents and its importance in the water bal ance of the region, U.S citizens keep a strong interest to continue with the same practice for the future. Citizens organizations support the idea to pay (In money) to Mexico its water rights. However this fact of possible payment is considered a merely conjecture (Morehouse, et al. 1999).

\section{CRITERIA 3: TO MAINTAIN WATER UNDER QUALITY STANDARDS ACCORDING TO ITS USE}

In general, evidence suggests that groundwater pumped from the Santa Cruz and Los Alisos well fields meets drinking water standards once it is sedimented and chlorined before to be served to N ogales, Sonora community. However, a third source, which is composed by a well-field over thecity of Nogales, Sonora, is highly polluted. Although during long time this local source of water was used for human consumption, it was no more than 5 years that this kind of use was apparently cancelled. Nevertheless, it is still used for other purposes, like irrigation. The city of Nogales, A rizona was the first in stopping the use its city well-fields for drinking purposes.

Sprouseet al (1996) statethat during last decadethe Santa Cruz County had experienced strong problems in itswater quality. They 
mentioned thehigher levels of Tetrachloroethylene(PCE) founded in Potrero Creek. As well as raw wastewaters, oil, heavy metals, DDT, parasites like Giardia, Cryptospodium and fecal coliform. The City of N ogales, Sonora still continue the exploitation of this source of water, principally to give supply to those city's zones without hydraulic infrastructure. The high drinking water demands may force this people the consumption of this water. Following sustainability criteria the city of Nogales, Sonora must stop in short time the use of this water for humans and relegate it as a secondary use like irrigation of unpaved roads, green areas, industrial processes, etc. This necessary practice has been influenced by international pressures rather than local initiatives.

It is also important to protect those wells which are still producing water of good quality; this can be possible implementing programs of protection. As a good example, the city of Nogales, Sonora had implemented a citizen initiative known as Well H ead Protection Program, with the main goal to assure that current aquifers sources continue bringing good quality supply through a strong land use regulations in an estimated well buffer protection zone. Others initiatives to monitor water quality and quantity in which the ADEQ (A rizona Department of Environmental Quality) cooperatively with Mexican institutions are the following: Binational Santa Cruz River Watershed Project (ADWR); Nogales Wash Joint U.S./ Mexico Groundwater Monitoring Project (with the IBWC); and theN ortheastern Sonora Water Quality Monitoring Project (with the ADHS).

A study titled "Programa binacional de Monitoreo de Aguas Subterráneas sobre el Arroyo Los N ogales" reported in 1998, had confirmed thehigh pollution levels, as well as thekind of pollutants existing in the Nogales Wash A quifer. In this binational effort, it was reported high PCE concentrations exceeding maximum concentrations level for the State of Arizona and Mexican standards. Also, this study report high levels of arsenic and nitrates. Furthermore, fecal coliforms and other compounds exceeding water quality standards were vinyl chloride, iron and Manganese. 
Estudios Fronterizos, Nueva época, vol. 4, núm. 7, enero-junio de 2003

In general, presences of pollutants compounds were verified by labs from both countries (IBWC, 1998).

\section{Criteria 4: TO Dispose of QuANTITATIVE ANd Qualitative WATER DATA}

In general terms we can state that in N ogales, Sonora there is not an adequate policy to produce information and make it available for people. Thus, is not so easy to obtain qualitative or quantitative water data. There are several reasons for this lack of data. First, because do no exist asystematized practice of water quality analysis from served waters; secondly, there is not a public pressuretoward the knowledge of this kind of information, due probably to the fact that community (in general) havea very poor perception about the health risks associated to the existence of water pollutant agents. In this sense, community ismoreconcerned with water supply in terms of quantity rather than its scrupulous quality.

The only source of existing and systematized official data for Nogales, Sonora is provided by the Mexican section of the International Boundary Water Commission (CILA, by its Spanish acronym). However, information is totally focused to quantitative hydrometric data. This information exists at a handout published in a yearly basis and there is not public access in digital formats. Conversely, the IBWC' U.S. section provide digital online information, which is available in a web-site. Thus, information exists in several formats for the community of Nogales, Arizona and also for rural communities of the Santa Cruz County. However, it is the community of N ogales, Sonora which needs to demand more data regarding to its water quality.

Criteria 5: to deVelop im Stitutional meChanisms

TO PREVENT AND TO SOLVE CONFLICTS ABOUT WATER USE

In this region, water conflicts exist at two main levels. First of them is the international order and the second one is of interregional level. For obvious reasons thefirst ones aremorecomplex to solve. 
Currently, the city of N ogales, Sonora present water conflicts with the municipality of Santa Cruz, Sonora. By thefuture, water basin transfers form Los Alisos Wash can bring conflicts with the municipality of Magdalena, Sonora. Besides, the city of N ogales, A rizona face water conflicts with its northern ward county, principally because the groundwater regulations over the use of water. Thus, wehavetheregion of A mbos Nogales facing complex water issues.

Fortunately, during last decade begun with a strong development of international institutions designed to solveenvironmental conflicts existing between México and the U.S. side. From the environmental problems, it is water the main subject of matter. Since first negotiations derived from the North A merican Free Trade A greements among M exico, Canada and the United States emerged a different manner to overcomeobstacles for management and water supply, particularly between Mexico and the U.S. In 1993, Border Environmental Cooperation Commission (BECC) and a founding mechanism named N orth A merican Bank Development (NADBank) werecreated. However, it was until 1996 when BECC, NADBank, and other municipal and state organisms recognized the priority to implement the "Proyecto Integral para Uso deAgua Potable, Tratamiento y Recarga" (PIAPTyR) en Nogales, Sonora. This project was planned to solve the permanent water supply problems, such as drinking and sewage water system in a frame of sustainable use of water in a binational region. PIAPTyR was designed to be implemented in two stages: 1) the first one has to do with carrying out hydraulic works and activities so as to change pipes and internal nets, as well as the construction of a peripheral water system; 2) second phase was considering the construction of new sources to obtain this vital element for both Nogales, as well as the construction of a wastewater treatment plant (Gobierno del Estado deSonora, 1995). Project was certified by BECc given that it had apparently satisfied environmental impacts criteria in Mexico, remaining to demonstrate environmental impacts for the United States (U.S. EPA, 1999). Phasel of PIAPTyR project foresees to warrant drinking water supply for the whole Nogales, Sonora 
population until the year of 2015 (Gobierno del Estado deSonora, SIUE, 1995). The estimated cost for these first phase was about 30 Millions, from which 50 percent was founded by the NADBank, 40 percent from fiscal founds from Mexico and the U.S. and the remaining 10 percent with private investment (N otiCOCEF, 1996).

Phase II of PIAPTyR project was conditioned because its international implications. This part was considering a significant pumping increase from the Santa Cruz Well fields located inside Mexican territory, passing from 300 liters per second to a pumping rate of about 600 liters per second. This fact had provoked a great reaction from the community of the Santa Cruz County whose was worried by the negative impacts of a higher depression cone in the M exican sideaffecting directly its ground water source. This fact was supported by technical studies performed by the Santa Cruz County Active Management A rea (SCAMA) and the A rizona Department of Water Resources (ADWR). It was demonstrated that a future depression cone provoked by a future ground water withdrawal in the Mexican sidecan increaseinduced recharge for the M exican side of about $7.7 \mathrm{M} \mathrm{m}^{3}$; affecting seriously theinduced recharge for heU.S. side. Furthermore, this new depression cone would affect directly the natural river's base-flow flowing to the U.S. side affecting the riparian wildlife of the Santa Cruz River (Cervera, 1996).

Moreover, this Phase II of the PIAPTyR project also had provoked a discouragement from rural Mexican producers, because a higher depression conewould affect directly its ground water resources used for agricultural and livestock activities. Finally, Second phase project was conditioned and depending upon hydrological studies developed in thebinational Santa Cruz River aquifer for institutions from both countries.

As a matter of fact, the increase of water pumping from Los Alisos Wash does not have international conflicts directly with theU.S. side, this because its expl oitation represent an inter-basin water transfer inside the mexican territory. Nevertheless, it is necessary to emphasize that this increased water input to the city of Nogales, Sonora will increase drastically its waste water 
generation. Cervera in 1995 estimated that the wastewater flows can change from 433 Ips to 920 lps. Former situation would oblige to changethescheme of the current binational water treatment to different sceneries which may include that Nogales, Sonora provides treatment of a portion of its wastewater effluent.

\section{CRITERIA 6: PLANNING AND DECISION MAKINGS CONSIDERING ALL INVOLVED PARTS}

This criterion is widely related with the above discussed. During developing and implementation of thePIAPTyR project supported by BECC and NADBank there was an important advance of democratization during decision processes, innovating with this in the Mexican side. BECC's criterion was based on community participation as key element. Thus, for the PIAPTyR certification process there were several international meetings which had included representatives from NGO's, academic sectors, ej idatarios, individual water users, institutions from municipal, state and federal levels, etc. (Perspectivas, 1996). Thus, a total of 22 meetings were held before project's certification (COCEF, 1995). In these meetings, main project's components were discussed, including founding mechanisms. During each session, participants have the opportunity to accept or refused this proposal (U.S. EPA, 1999).

Democratic participation helping to solvewater issues aremore advanced in the city of N ogales, A rizona, where in general people is more concerned and involved during decision processes. The Right to Know philosophy carried out by NGO'S principally promotes that peopleis very well informed about local water issues affecting its own lives and their ecosystems. To deal with binational water issues, communitarian groups to work in a binational agenda were leaded by U.S. citizens. Principal efforts of this initiatives was focused on collection of vital information for communities of both countries, which include: 1) Interpretation and dissemination of water data in an accessibleformat for community; 2) Distribution and sharing information in a bilingual format; and 3) Inclusion of representative of all community and government levels. 
Estudios Fronterizos, Nueva época, vol. 4, núm. 7, enero-junio de 2003

Criteria 7: human ACTIONS WILL NOT AFFECT THE RENEWABILITY WATER RATES OF THE AQUIFERS AND SURFACE WATERS

Current water exploitation regimeto providewater supply in Both N ogal es region from the Santa Cruz River's aquifer is about 15.0 $\mathrm{Mm}^{3}$ / year. From this figure, $9.46 \mathrm{Mm}^{3}$ (63\%) correspond to the city of N ogales, Sonora and the remaining $5.7 \mathrm{M} \mathrm{m}^{3}$ correspond to the City of Nogales, Arizona. This combined extraction is equivalent to the 62 percent of the natural recharge capacity of the Santa Cruz River estimated in $24 \mathrm{M} \mathrm{m}^{3} /$ year. Studies reported by Cervera in 1997 establish that only for irrigation purposes in the Mexican side were pumped a total of $11 \mathrm{Mm}^{3}$ to irrigate two agriculture cycles. Thus, if former figures are sum up, then the combined extraction is about $26 \mathrm{Mm}^{3}$. These figures suggest that water extraction is greater than natural recharge; as a consequence, this region is under hydrologic imbalance. In this semi-arid region, the NITWWP' effluent constitute an invaluable water resource, which is being used only for the U.S. side with its inherent ecosystems benefits as was discussed in above sections. Induced aquifer recharge by this concept al lows that the Santa Cruz County Active Management A rea is considered in hydrologic equilibrium. In this sense, this kind of practices mitigates human actions over the environment. A water balance presented by Morehouse et al (2000) reveals that the region of N ogales, A rizona insidethesCAMA have a negative average water bal ance of above $-6.896 \mathrm{ac}-\mathrm{ft} / \mathrm{year}$ (-8.5 M m³ year) estimated between 1992 and 1995. It is with the NIWWTP' effluents of about $11.46 \mathrm{M} \mathrm{m}^{3} /$ year plus other effluents produced inside the SCAMA (5,019 ac-ft/ year) that is balance became to a positive amount of about $11.46 \mathrm{Mm}^{3}$. As a conclusion the wastewater treated effluents are the main factor allowing a safe yield situation, where water demand is in balance with the renewable water supply.

The natural system more highly impacted is represented by the Nogales Wash sub-basin, which is covered in a high proportion for urban land use. This impact had been affected it in such a way that its groundwater need to be excluded for any human direct use. 


\section{CONCLUDING REMARKS}

The studied region presents important indicators revealing good advances pursing a sustainable use of water in a binational context. From A mbos N ogales, current water management practiced in the U.S. side is more close to fulfill the set of guidelines driven to a sustainable use of water. As a consequence, in this region theU.S. sidehas a more equilibrated management of their water resources, which al low a secure supply in both quantity and quality for total population and also to provide a secure future supply until the 2040 year. A pparently, it is the size of its population the main factor allowing better management of water resources. Strong policies to preserveriparian ecosystem of theSanta Cruz River had allowed the restoration of riparian habitat at a significant length. This had been possible by the use of the effluent generated from the NIWWTP.

In the Mexican sidesituation is quitedifferent. Thecurrent water management looks so far to fulfill sustainability criteria, being this reflected in the quality of life of its population and al so of its natural resources. For instance, in several sectors of this city thedrinking water delivered can beconsidered with doubtful quality and with important deficits of supply. Besides, still there areentirecolonias without drinking water supply and sewerage system. Policies of recycling wastewater for possi ble secondary uses are no cl ear yet. However, implementation of the PIAPTyR project will help to solve in a significant way the current water issues.

The creation of binational institutions to solve environmental problems in the border area between Mexico and the Unites States, such as BECC and NADBank, represents and advancefor handling shared natural resources, what implies action in which the region has the principal role in making decisions. PIAPTyR constitutes the best example of interaction at binational level to solve problems managed by only one country before.

The binational water issues studied here are in some manner repetitive for the whole U.S.-Mexico border where twin cities subsist sharing water resources. The future obliges us to face the 
challenge of a better binational management of our natural resources and environmental issues.

\section{REFERENCES}

Alegría, T. 1990. Ciudad y Transmigración en la Frontera de M éxico con Estados Unidos, Frontera N orte 2(4): 7-38.

Arizona Department of Water Resources (ADWR). 1995. «EvaIuation of the Effects of Increased Mexican Use of Groundwater in theSanta Cruz River Watershed». N ogales, A rizona. A rizona D epartment of W ater Resources (A DWR). 1998. M exican D rainage. [0 $n$ line] A vailableat: <http:/ / www.adwr.state.us/ AZWaterinfo/ Watersheds/ mexicandrainage.html>

Barrios, J.L. and L.E. Cervera. 2000. «M edio Ambientey Conformación U rbana dela Ciudad deN ogales», mimeo.

Sonora: panaroma actual y perspectivas, in: Rubén Sandoval (eds.), A ctas del II y III Coloquios Internacionales La Frontera: una nueva concepción cultural. Universidad Autónoma de Baja California Sur.

Cervera, L.E. 1997. “Planeación de la Demanda deA gua en N ogales, Sonora: La Sustentabilidad de su Utilización en una Región", in: en Ma. Gpe. García y Alejandro Mungaray (eds.), D esarrollo Fronterizo y Globalización, ANUIES, Universidad de Sonora y Colección Biblioteca deEducación Superior, pp. 185198.

COCEF. 1996. "Criterios Para la Certificación de Proyectos". Cd. Juárez, Chihuahua. [Online] Available at: http:/ / COCEF.interjuarez.com

COCEF. 1996. "Formato Para la Presentación deProyectos". Proyecto Integral Para Uso deA gua Potable, Tratamiento y Recarga en N ogales, Sonora.

Condes, D.T. 1970. " Streamflow in the Upper Santa Cruz River Basin, Santa Cruz and Pima Counties, Arizona", in: Water Resources of theT ucson Basins. U.S. Government Printing Office: 1970 0-397-785. 
Jana, F. and L.E. Cervera. 1995. "Water resources in the Upper Santa Cruz River Basin". Bilingual Report of the Border Environmental Action Team published by the Center for Environmental Studies of A rizona StateUniversity and El Colegio de la Frontera N orte.

Gleick, P., L.G. Gomez and J. Morrison. 1995. Cal ifornia W ater 2020: A Sustainable V ision. The Pacific Institute for Studies and Development, Environment, and Security. Oakland, California.

Hogan, P. 1993. “Capacidad de Carga Poblacional: rehabilitando un concepto", in Izazola H. and S. Lerner (eds.), Población y A mbiente, Mexico, D.F., pp. 84-85.

IBWC. 1998. Binational Nogales Wash Unites States/ Mexico Groundwater Monitoring Program Interim Report, pp. 5. [Online] Available at: http:/ / www.ibwc.state.gov/ Files/ Nogwashr.htm

Ingram, H. N.K. Laney, N.K. and D.M. Gillian. 1995. D ivided W aters:

Bridging the U S.-M exico Border, The University of Arizona Press; Tucson, Arizona.

Loucks, D. y J. Gladwell. 1999. Sustainability Criteria for Water Resource Systems, United Kingdom: Cambridge University Press.

Morehouse, B., R. Carter, T. Sprouse. 2000. "The Implications of SustainableDrought for Transboundary Water Management in N ogales, A rizona, and N ogales, Sonora". N atural Resources Journal, 40: 783-817.

Morrison, J., S. Postel and P. Gleick. 1996. “The Sustainable Use of Water in the Lower Colorado River Basin". A joint report of thePacific Institutefor Studies in Development, Environ-ment, and Security and the Global Water Policy Project.

OECD. 1998. Toward SustainableD evelopment: Environmental indicators. France: OECD publications.

Patten, D. 2002. “Development of best management practices for water and riparian resources al ong theSanta Cruz Watershed", U.S./ M exico Border. SCERP Project Number: P-18. 
Pick, J., N. Viswanathan and J. Hettrick. 2001. The U.S.-M exican Borderlands Region: a binational spatial analysis", TheSocial Science Jurnal (38): 567-595.

Rubio, R. 2001. “M ovilidad Temporal Laboral en la Frontera N orte de México, 1995". Treballs de la Societat Catalana de Geografía (51): 153-176.

Semarnap/ Profepa. 1997. Ley General del Equlibrio Ecológico y la Protección al A mbiente, México, D.F.

Sprouse, T., D. Cory and R. Varady. 1996. "Aquifer Contamination and Safe Drinking Water: the Recent Santa Cruz County Experience", Hydrology and Water Resources in A rizona the Southwest (26).

Samson, P. and B. Charrier, 1997. International Freshwater Conflict: issues and prevention strategies. [Online] Availabeat : http:/ / dns.gci/ water/ gcwater/ study.html

Schwalen, H.C. and R.J. Shaw. 1957. Groundwater Supplies of Santa Cruz V alley of Southern A rizona B etween Rillito Station and the International Boundary. University of A rizona, Tucson.

U.S.E.P.A. 1999. «Environmental Assessment for Water System Improvements». City of N ogales, Sonora, M exico.

Woodard, D. and R. Durall. 1996. United Sates-Mexico Border A rea, as Delineated by a Shared-Water Resources Perspec-tive. United States Department of the Interior, Fact Sheet 1, February. 